\title{
Influence of poly-enzyme preparation "Universal" on the meat productivity of Cherry-Valley ducks
}

\author{
Oleg Yakimov, Munira Gainullina, Denis Aksakov, and Mohamed Dandrawy
}

Kazan State Academy of Veterinary Medicine, 420029 Kazan, Russia

\begin{abstract}
Antibiotics widely used in poultry farms can have a harmful effect on meat consumers through chemical residues. Thus, it is important for the safety of customers to find a natural alternative. The purpose of this study was to evaluate the effectiveness of adding a polyenzyme preparation "Universal", containing amylosubtilin (1300 U/g), protosubtilin (67 U/g) and celloviridine $(2000 \mathrm{U} / \mathrm{g})$, on the productivity of broiler ducklings of the Cherry Valley breed. The results of research have shown that the addition of the "Universal" drug in the diet helped increase the meat productivity of broiler ducks. The use of the "Universal" drug contributed to the better development of internal organs (heart, liver and stomach) in broiler ducks. The improvement in duck weight and meat yield may be attributed to the fact that the feed protein is best consumed under the influence of protosubtilin, one of the "Universal." It is understood that protosubtilin supplies digestible peptides and amino acids with hydrolysis of plant proteins from grain raw materials, enhances the gastrointestinal tract's enzymatic history, compensates for the loss of depleted digestive enzymes and at the early stages of animal growth. Thus, the results of the experiment showed that the use of the drug "Universal" in the cultivation of broiler ducks of the cherry valley breed increases the pre-slaughter and slaughter weight, meat yield and reduces feed conversion, which is economically profitable. Therefore, it is recommended to use the drug "universal" as part of ration for broiler ducklings.
\end{abstract}

\section{Introduction}

In conditions of advanced meat production technology, providing the poultry industry with full-fledged compound feeds and feed additives is an important factor of increasing poultry productivity. The organization of a balanced diet that meets the needs of poultry in nutrients and vitamins at a certain physiological state and level of productivity is one of the main factors of successful poultry meat production [1-4].

An essential component of full-balanced ration for poultry is enzyme preparations which contribute to the breakdown of difficult-to-hydrolyze components of plant feeds (non-starch polysaccharides (NSP), alkylresorcinols, phytates, etc.), increase the digestibility of feed nutrients, growth intensity and a significant reduction in feed conversion.

The degree of activity of enzyme preparations depends on the $\mathrm{pH}$ level of the medium. For example, phytase is most active in an acidic environment at a $\mathrm{pH}$ of 2:3.5, which is present in the stomach, and intestinal enzymes need a neutral $\mathrm{pH}$ level of 6:6.5 for maximum activity. Another factor is the stability of enzymes to the effects of digestive enzymes, in particular pepsin of the stomach [5-8].
Ducks were historically a relatively small component of the global poultry industry, but there has been a recent development. When demand has increased worldwide, the quality of the production of duck meat has become ever more important. The nutritional formula is a vital economic factor because feed accounts for a large portion of the cost of poultry raising. To optimize the efficiency of duck meat, the determination of optimal duck nutrition is important to achieve the best live performance for ducks. However, our knowledge of the impact in duck diets of feed additives is still far behind our knowledge of that in chickens $[9,10]$.

Feed is currently the key factor for industrial production of livestock. Non-starch polysaccharide (NSP), however, is used to interrupt the food intake of carbohydrates and protein, since monogastric animals have no auto-enzymes to digest them. supplementation using exogenous enzymes is widely used to increase the digestibility of NSP and protein. Water-insoluble NSPs are considered practically indigestible, and birds only digest partially soluble NSPs, whereas NSPs increase digestive viscosity, reduce nutrient digestibility and suppress growth [9-12].

Earlier studies have shown a single or more complex enzyme, such as carbohydrases, and phytase can increase nutrient usage, thereby reducing feed costs in the production of poultry. Phytase releases phosphorous

\footnotetext{
Corresponding author: tppsxp@mail.ru
} 
effectively through hydrolyzing phytate phosphorous compounds. After 10 days, adding of 500, 1,000, and 1,500 units of phytase to basic diet for 7-day old ducklings causes releasing of $0.453,0.847$, and $1.242 \mathrm{~g}$ of inorganic $\mathrm{P} / \mathrm{kg}$ of diet respectively [12].

The data of Francesch and Geraert showed that the supplementation with a multi-enzyme complex containing NSP degrading enzymes and phytase is very effective in compensating the down-spec from the reduction of $2.0 \mathrm{~g} / \mathrm{kg}$ available phosphorus (avP), 85 $\mathrm{kcal} / \mathrm{kg}$ apparent metabolizable energy (AME), as well as $3.0 \%$ digestible amino acids (DAA) of corn-soybean meal diets in broilers. [13].

In this regard, the development of new feed enzymes that are resistant to the effects of digestive enzymes with high activity in the gastrointestinal tract of poultry is relevant. In early studies, we established the high efficiency of the new poly-enzyme preparation Universal in the cultivation of broiler chickens and turkey poults $[14,15,17]$.

The purpose of the research was to study the effect of feed enzyme additive "Universal" on the meat productivity of Cherry Valley ducks.

\section{Materials and methods}

In order to carry the experiment on the principle of balanced groups, a total of 200 Cherry Valley ducklings were formed into 2 groups at the age of 7 days. The live weight of the control group was $240 \pm 4.5 \mathrm{~g}$, and the second experimental group was $238 \pm 5.0 \mathrm{~g}$. Control and experimental group birds received complete feed: at the age of 1-3 weeks - (PK-21), at the age of 4-8 weeks-(PK22). The ration of ducklings of the experimental group additionally included poly-enzyme preparation "Universal" in a dose of $0.1 \mathrm{~g} / 1 \mathrm{~kg}$ of feed. Poly-enzyme preparation "Universal" contains amylosubtilin (1300 $\mathrm{u} / \mathrm{g})$, protosubtilin $(67 \mathrm{u} / \mathrm{g})$ and celloviridine $(2000 \mathrm{u} / \mathrm{g})$.

The duration of the scientific-economic experience was 38 days. During the experiment, all physiological studies were assessed by the general appearance, behavior, feeding and drinking quantity, as well as by the results of biochemical blood tests. The live weight was recorded weekly, starting from the daily age during the entire growing period, and the livestock was weighed individually.

The safety of livestock of the control and experimental groups was taken into account by counting the death cases of the livestock. At the end of the experiment, a controlled slaughter of the experimental bird was carried out. After the slaughter, the anatomical cutting of the carcass was carried out, the slaughter yield, the yield of edible and inedible parts was determined.

All protocols for experiments with birds were carried out in full compliance with the guidelines for animal care and were approved by the Animal Care Committee from Kazan State Academy of Veterinary Medicine named after (N.E. Bauman.

\section{Results and discussion}

\subsection{Changes in the live weight of poultry}

Through the whole period of the experiment, both control and experimental ducklings had a good food appetite, a good response to many external stimuli, no symptoms of any illness or deficiency. feces had a normal appearance, color and consistency, with no indigestive signs, thus showing the gastrointestinal tract's normal function.

In the course of the research, it was found that ration with "Universal" drug contributed to an increase in the average daily growth and live weight of experimental birds (Table 1, Figure 1, Figure 2).

Table 1. Zootechnical indicators of the experiment.

\begin{tabular}{|c|c|c|}
\hline Parameters & Control group & $\begin{array}{l}\text { Experimental } \\
\text { group }\end{array}$ \\
\hline $\begin{array}{l}\text { The safety of livestock, } \\
\%\end{array}$ & 97 & 98 \\
\hline $\begin{array}{l}\text { Live weight, g: } \\
\text { at the age of } 7 \text { days } \\
\text { at the age of } 45 \text { days }\end{array}$ & $\begin{array}{c}240 \pm 4.5 \\
3330 \pm 36.9\end{array}$ & $\begin{array}{c}238 \pm 5.0 \\
3410 \pm 41.7\end{array}$ \\
\hline $\begin{array}{l}\text { Average daily body } \\
\text { weight gain, } g\end{array}$ & $81.3 \pm 5.6$ & $83.5 \pm 7.2$ \\
\hline $\begin{array}{l}\text { Absolute increase in live } \\
\text { weight, } g\end{array}$ & $3090 \pm 12.5$ & $3172 \pm 23.1$ \\
\hline In $\%$ to control & 100.0 & 102.7 \\
\hline Feed conversion, $\mathrm{kg}$ & 2.21 & 2.16 \\
\hline $\begin{array}{l}\text { European performance } \\
\text { index }\end{array}$ & 384.6 & 407.1 \\
\hline
\end{tabular}

According to table 1, it can be noticed that the average daily increase in live weight of broiler ducks of the first control group was $81.3 \pm 5.6 \mathrm{~g}$, and the second experimental group of birds receiving the Universal drug was $83.5 \pm 7.2 \mathrm{~g}$. Therefore, by the end of the experiment, the live weight of poultry in the experimental group was $2.7 \%$ higher $(3172 \pm 23.1 \mathrm{~g})$. The feed conversion in the experimental group decreased by $2.3 \%$. 


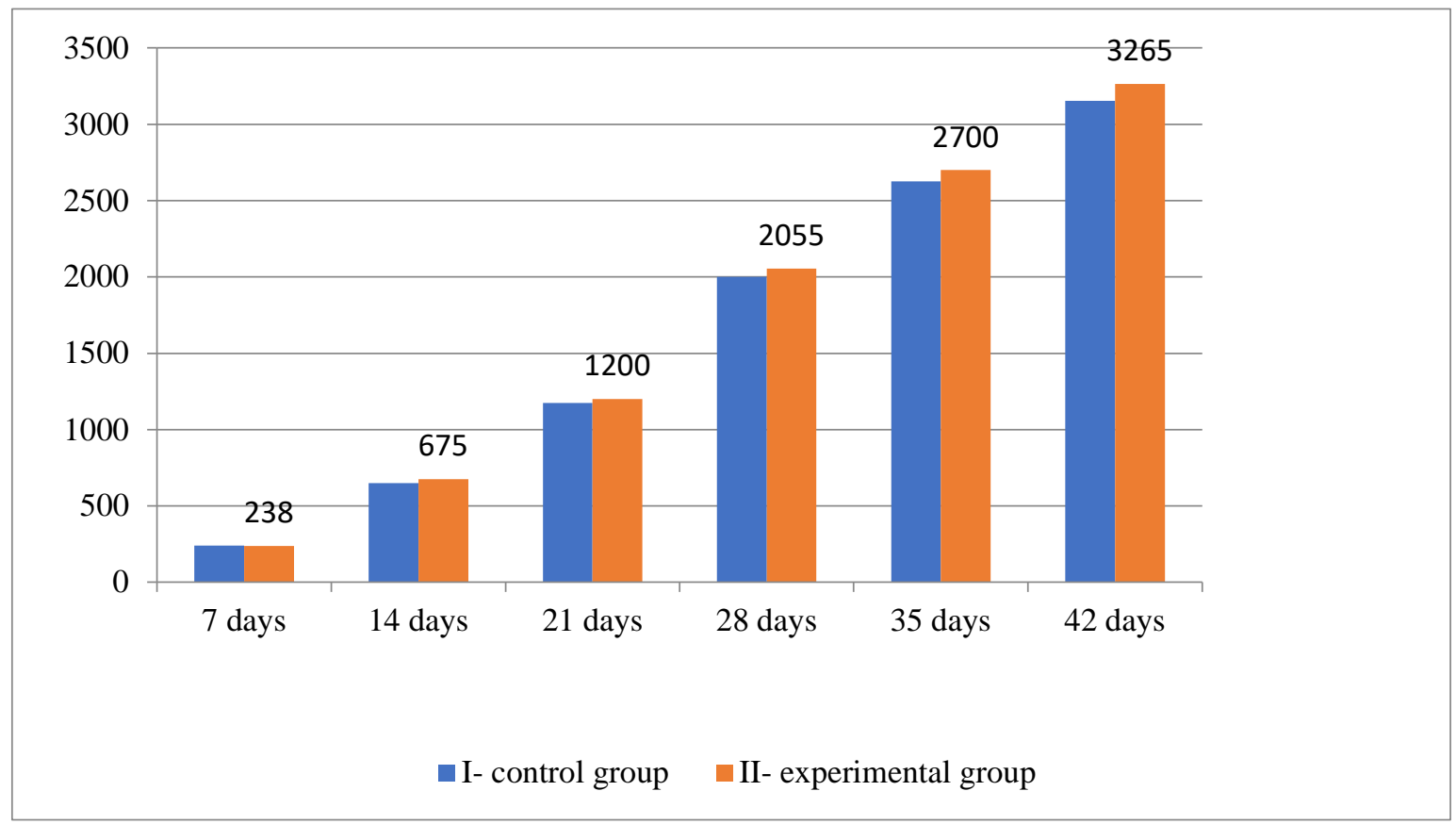

Fig. 1. Dynamics of live weight of ducks during the experiment period, g.

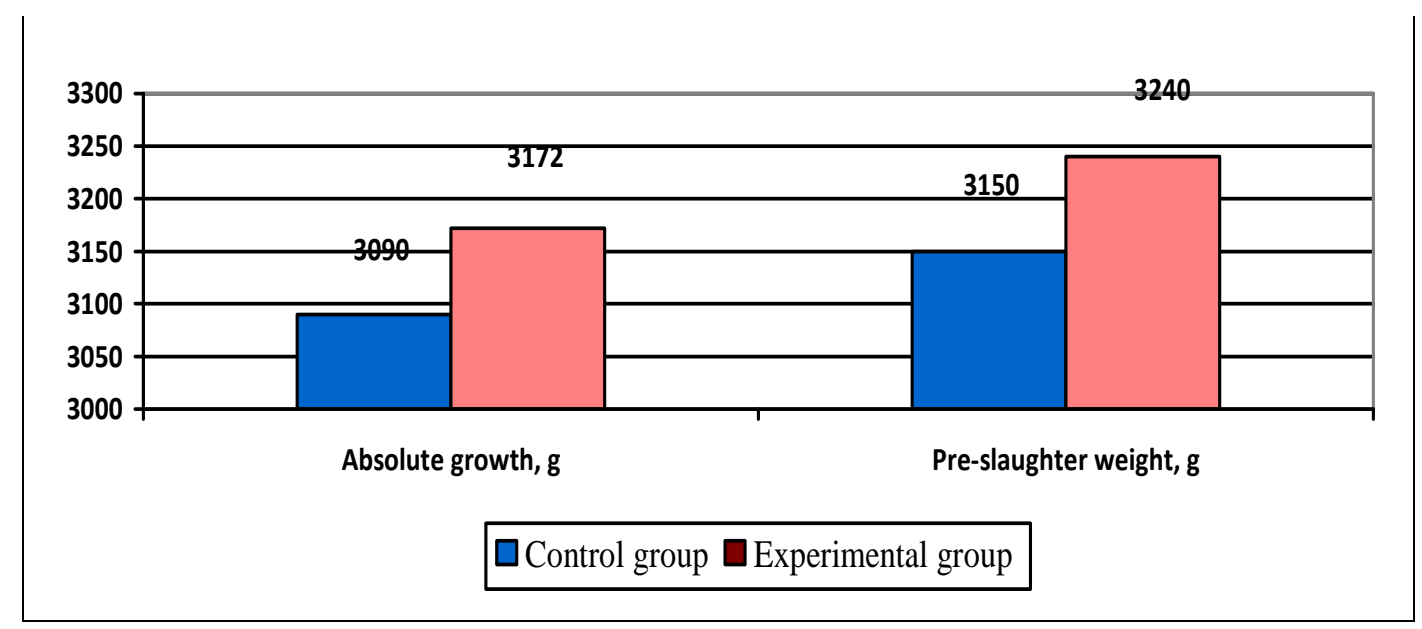

Fig. 2. Absolute growth and live weight of ducks in 45 days.

\subsection{Enzymatic activity}

The obtained results indicate that under the effect of enzymes that are part of the "Universal", there is an increase in the digestibility of feed nutrients. It is known that amilosubtilin catalyzes the hydrolysis of $\alpha-1,4-$ glycosidic starch bonds, which leads to a rapid decrease in the viscosity of gelatinized starch solutions and the formation of low-molecular dextrins. In this case, the overall effect of amilosubtilin is associated with the combined effect of the drug's constituent enzymes (betaglucanase, xylanase, and cellulase), which catalyze the splitting of difficult-to-digest polysaccharides of barley and wheat feed, hydrolysis of which gives an additional amount of sugars.

In addition to, celloviridine destroys the walls of plant cells, increases the availability of starch, protein and fat for the effects of digestive tract enzymes and digestibility of nutrients, improves their absorption in the small intestine, eliminates the negative effect of antinutritional factors that affect the absorption and use of nutrients, improves the microbiological environment of the intestine by reducing the viscosity and increasing the level of monosaccharides. [16, 18, 19].

Phytases have been well established by chickenbased studies to affect phosphorus and calcium absorbance. The use of phytase in broiler chicken diets by Kalmendal and Tauson has been reported to improve the live performance and digestibility of nutrients [20].

\subsection{Meat productivity}

Analyzing the results of the controlled slaughter ducks, it should be noted that the poultry that received a polyenzyme preparation with mixed feed had higher meat productivity indicators (table 2).

According to our data, feeding the enzyme preparation Universal as part of compound feeds contributed to an increase in the pre-slaughter weight of

\footnotetext{
* Corresponding author: tppsxp@mail.ru
} 
broiler ducks by $2.8 \%$ and meat yield by $1.5 \%$, as well as better development of internal organs (heart, liver, and stomach). The absolute weight of the heart in the experimental group of birds was $16.5 \pm 2 \mathrm{~g}$, the liver$58.0 \pm 3.1 \mathrm{~g}$, the stomach-77.0 $44.5 \mathrm{~g}$, relative to the preslaughter weight they were $0.51 \%, 1.79 \%$ and $2.88 \%$, respectively. Thus, the increase in the mass of internal organs in the experimental bird was proportional to body weight.

Table 2. Weight of carcasses and internal organs of ducks.

\begin{tabular}{|l|c|c|}
\hline \multicolumn{1}{|c|}{ Parameters } & $\begin{array}{c}\text { Control } \\
\text { group }\end{array}$ & $\begin{array}{c}\text { Experimental } \\
\text { group }\end{array}$ \\
\hline Pre-slaughter weight, g & $3150 \pm 60.0$ & $3240 \pm 55.0$ \\
\hline$\%$ control & 100.0 & 102.8 \\
\hline $\begin{array}{l}\text { Weight of the gutted } \\
\text { carcass, g }\end{array}$ & $2147 \pm 34.0$ & $2216 \pm 50.0$ \\
\hline$\%$ to control & 100.0 & 103.2 \\
\hline Meat yield, \% & 64.5 & 65.0 \\
\hline $\begin{array}{l}\text { Byproducts: } \\
\text { heart, g }\end{array}$ & $15.5 \pm 1.5$ & $16.5 \pm 2.0$ \\
\hline$\%$ of pre-slaughter weight & 0.49 & 0.51 \\
\hline liver, g & $55.0 \pm 2.4$ & $58.0 \pm 3.1$ \\
\hline$\%$ of pre-slaughter weight & 1.75 & 1.79 \\
\hline Stomach, g & $74.0 \pm 2.6$ & $77.0 \pm 4.5$ \\
\hline$\%$ of pre-slaughter weight & 2.35 & 2.38 \\
\hline
\end{tabular}

In the control group, the mass of the gutted carcass was $2147 \pm 34.0 \mathrm{~g}$, while, in the experimental group$2216 \pm 50.0 \mathrm{~g}$, the meat yield in the control and experimental groups was $64.5 \%$, and $65.0 \%$, respectively. The increase in meat yield can be explained by the fact that under the influence of protosubtilin, which is in the content of the Universal preparation, the feed protein is better absorbed. It is known that protosubtilin provides hydrolysis of plant proteins of grain raw materials for digestible peptides and amino acids, complements the enzymatic background of the gastrointestinal tract, compensates for the deficit of digestive enzymes under stress and in the early stages of animal development $[1,2,17,19]$.

The results of $\mathrm{Yi}$ Zongrong et al., showed that the compound enzyme supplementation in wheatmiscellaneous meal diets improved significantly the Cherry Valley drakes' body weight (P 0.01 ), whereas the effects of compound enzyme preparations the best results were obtained in the group, with the increased levels of xylanase, mannanase, $\beta$-glucanase, cellulase, amylase, saccharifying enzyme, acid protease and neutral protease

at $4320000,14400,446400,69120,160,3000,1000$, and 1000 $\mathrm{U} / \mathrm{g}$, respectively. Furthermore, in comparison with the control group, the feed gain ratio of group added compound enzyme preparations decreased significantly [21].

While, according to Martin et al., phytase had no significant impact on live duck results, furthermore, the authors found that lysine and threonine digestibility in vegetable protein diets is positively influenced by phytase, suggesting again that efficacy depends on dietary ingredients [22].

There are several potential explanations for different outcomes in the previous experiments. Firstly, advanced biotechnologies have increased the efficiency of the enzymes in the last decade. Different enzyme levels in the foods $(850,1,000$ and $10,000 \mathrm{U} / \mathrm{kg})$ are the second possibility. In addition, since mono-calcium phosphate has more than di-calcium phosphates available, it can be better to absorb phosphorus in the intestine by certain enzymes, the difference between mono- and di-calcium phosphate can also play a role.

\section{Conclusion}

Thus, the results of the experiment showed that feeding ducks with compound feed enhanced with the preparation "Universal" in a dose of $0.1 \mathrm{~g} / 1 \mathrm{~kg}$ of feed increases the meat productivity of broiler ducks of the Cherry Valley breed. Compared with the control group, the experimental poultry had the best indicators of meat productivity: pre-slaughter weight $(3240 \pm 55.0 \mathrm{~g})$, mass of the gutted carcass $(2216 \pm 50.0 \mathrm{~g})$, meat yield of $65 \%$ while reducing feed conversion by $2.3 \%$, which is economically profitable.

Therefore, we can conclude that the new polyenzyme preparation "Universal" is resistant to the effects of digestive enzymes and shows high activity in the gastrointestinal tract of poultry. Since the drug has amylolytic, proteolytic, cellulolytic, glucanase and xylanase activity, it probably contributes to the breakdown of difficult-to-hydrolyze substances of plant feeds (non-starchy polysaccharides, alkylresorcinols, phytates, etc.), increases the digestibility and digestibility of protein and fiber feed. Therefore, we can recommend this drug as part of compound feeds for broiler ducklings in order to increase meat productivity and reduce feed conversion.

A more in-depth study of the biochemical processes that occur under the influence of the drug in the poultry body, as well as its enzymatic activity, depending on the composition of the grain part of compound feeds, is promising in order to improve the effectiveness of the use of the drug in the poultry raising industry.

\section{References}

1. U. Gadde, H. Kim, T. Oh, S. Lillehoj, Anim. Health. Res. Rev., 18, 26-45 (2017)

2. A. Slominski, Poult. Sci., 90, 2013-2023 (2011)

3. E. Papunidi, Bulletin of the Mari State University. Series: Agricultural Sciences. Economics, 2(18), 191-196 (2019)

4. L. Pykhtina, V. Ulitko, O. Erisnova, Bulletin of the Ulyanovsk State Agricultural Academy, 4(16), 9599 (2011)

5. K. Munir, S. Maqsood, Emir. J. Food. Agr., 25, 6680 (2013)

6. B. Knudsen, Poult. Sci., 93, 2380-2393 (2014) 
7. A. Kiselev, I. Vasilchenko, L. Kiselev, O. Yudina, The Zootechny, 8, 28 (2013)

8. S. Kononenko, Veterinary medicine of farm animals, 1-2, 11-14 (2018)

9. R. Coppedge, L. Oden, B. Ratliff, B. Brown, F. Ruch, J. Lee, J. Appl. Poult. Res., 21, 226-234 (2012)

10. R. Timmler, M. Rodehutscord, Arch. Anim. Nutr., 55, 315-332 (2001)

11. M. Xie, J. Zhao, S. Hou, W. Huang, Anim. Feed. Sci. Technol., 157, 95-98 (2010)

12. F. Gao, Y. Jiang, G. Zhou, Z. Han, Br. Poult. Sci., 48, 480-488 (2007)

13. M. Francesch, P. Geraert, Poult Sci., 88, 1915-1924 (2009)

14. O. Yakimov, A. Volostnova, M. Gainullina, Scientific Notes of Bauman Kazan State Academy of Veterinary Medicine, 204, 333-337 (2010)
15. O. Yakimov, M. Gainullina, D. Aksakov, RJPBCS, 10(1), 1716-1722 (2019)

16. J. Park, B. John, J. Appl. Poult. Res., 28, 587-597 (2019)

17. M. Grigoriev, O. Yakimov, Scientific Notes of Bauman Kazan State Academy of Veterinary Medicine 235(3), 41-44 (2018)

18. V. Lavrenova, Agricultural review "Tsenovik," 5, 64-73 (2017)

19. A. Lobanok, Science and innovation, 12(106), 61-64 (2011)

20. R. Kalmendal, R. Tauson, Poult. Sci., 91, 1387-1393 (2012)

21. Y Zongrong, Z Hui, F Tangchao, Cereal \& Feed Industry, 7 (2013)

22. E. Martin, J. Nolan, Z. Nitsan, D. Farrell, Brit. Poult. Sci., 39, 612-621 (1998) 